\title{
EDUKASI POLA HIDUP BERSIH DAN SEHAT SERTA PENERAPAN ADAPTASI KEBIASAAN BARU PASCA PANDEMI COVID19
}

\author{
Saipul Al Sukri ${ }^{1)}$, Zulfahmi $^{2)}$, Irfan Ridha ${ }^{2)}$, Abdiana llosa $^{1)}$, Zulhaida $^{1)}$, \\ Nurrahmi Hayani ${ }^{1)}$, Rahmadeni $^{3)}$, Darni ${ }^{4}$, Hakmi Wahyudi $^{4)}$ \\ 1)Fakultas Ekonomi dan Ilmu Sosial Universitas Islam negeri Sultan syarif Kasim \\ 2) Fakultas Syariah dan Hukum Universitas Islam negeri Sultan syarif Kasim \\ 3) Fakultas Sains dan Teknologi Universitas Islam negeri Sultan syarif Kasim \\ 4) Fakultas Tarbiyah dan Keguruan Universitas Islam negeri Sultan syarif Kasim \\ saipul.a.sukri@uin-suska.ac.id
}

\begin{abstract}
Abstrak
E-Warong Berkah Harapan merupakan salah satu tempat penyaluran paket bantuan program SEMBAKO, melayani hampir 400 Orang penerima bantuan setiap bulannya. Kerumunan yang terjadi bukan tidak mungkin menimbulkan clutser penularan baru Covid19. Oleh sebab itu, Tim pengabdi dari UIN Sultan syarif Kasim melakukan penyuluhan mengenai "Edukasi Pola Hidup Sehat serta penerapan Adaptasi Kebiasaan Hidup baru Pasca Pandemi Covid19". Sebelum dilakukan penyuluhan, kegiatan penyaluran paket SEMBAKO mengabaikan jaga jarak minimal 1 meter, tidak menggunakan masker dan belum tersedianya sarana cuci tangan yang memadai. Hasil pre-test tentang pengetahuan pengurus juga menunjukkan rata-rata skor tes yang cukup rendah, sebesar 49,77. Setelah dilakukan penyuluhan hasil post-test menunjukkan kenaikan yang cukup tinggi dengan rata rata skor 91,14. Kenaikan ini menunjukkan pengetahuan pengurus yang bertambah dari sebelumnya. Kegiatan pengabdian juga disertai dengan penyerahan perlengkapan alat pelindung diri untuk pengurus berupa face shield, masker, handsanitaizer, sabun cuci tangan, sarung tangan plastik dan tong cuci tangan. Diharapkan rantai penularan covid19 dapat diputus dan pengurus e-Warong dapat melakukan pekerjaannya dengan baik dan lancar.
\end{abstract}

Kata Kunci: New Life Habits, E-Warong, Covid19

\begin{abstract}
E-Warong Berkah Harapan is one of the places where the SEMBAKO program aid packages are distributed, which serves nearly 400 aid recipients every month. The crowd that occurred was not impossible to cause a new transmission clutser for Covid19. Therefore, the service team from UIN Sultan Syarif Kasim conducted counseling on "Education on Healthy Lifestyle and the application of Adaptation to New Life Habits Post-Covid19 Pandemic". Before the counseling was carried out, the SEMBAKO package distribution activities neglected to maintain a minimum distance of 1 meter, did not use a mask and did not yet provide adequate hand washing facilities. The pre-test results about the management's knowledge also showed that the average test score was quite low, amounting to 49.77. After counseling, the post-test results showed a fairly high increase with an average score of 91.14. This increase shows that the management's knowledge has increased from the previous one. The service activity was also accompanied by the handing over of personal protective equipment for administrators in the form of face shields, masks, hand sanitizers, hand washing soap, plastic gloves and hand washing vats. It is hoped that the covid19 transmission chain can be broken and e-Warong administrators can do their job well and smoothly.
\end{abstract}

Keywords: New Life Habits, E-Warong, Covid19 
Saipul Al Sukri, dkk. Edukasi Pola Hidup Bersih Dan Sehat Serta Penerapan...

\section{PENDAHULUAN}

Tidak pernah diprediksi sebelumnya akan terjadi wabah yang berdampak sangat besar pada setiap lini kehidupan kita. Hal yang dulu dengan leluasa kita lakukan, saat ini sudah tidak dapat lagi kita lakukan. Interaksi sosial saat ini sebagian besar dilakukan secara virtual. Secara sadar pandemi ini telah memunculkan kebiasan-kebiasaan baru, melompati apa yang biasanya kita lakukan. Inilah perilaku kehidupan baru, mau tidak mau kita dipaksa untuk beradaptasi dan menjadikan norma baru dalam kehidupan keseharian kita.

Menurut (Rothan \& Byrareddy, 2020) Coronavirus merupakan salah satu patogen yang keberadaannya menyerang sistem pernapasan manusia, merusak miokardium yakni lapisan otot jantung yang bertanggung jawab dalam pemompaan jantung (Zheng, Ma, Zhang, $\&$ Xie, 2020). Pada banyak kasus, virus ini akan menyebabkan infeksi ringan pada pernapasan, seperti flu. Namun, pada kasus serius virus ini bisa mengakibatkan hal yang lebih berat, seperti infeksi paruparu (pneumonia), kesulitan bernapas. Penelitian terbaru menyebutkan bahwa secara epidemiologi virus ini bersumber dari makanan laut dan hewan basah yang diperjual belikan di pasar Wuhan Provinsi Hubei, China (Lu, Stratton, \& Tang, 2020), (I.I. et al., 2020). Kasus pertama terjadi pada pertengahan Desember 2019 dengan diagnosa awal sindrom pernapasan akut. Penyebaran virus ini terjadi sangat cepat, salah satunya disebabkan banyak pasien di luar rumah sakit yang luput dari pantauan tim dokter. Pada akhir Januari 2020 kasus positif terkonfirmasi di China mencapai 7.734 dan dilaporkan juga tersebar di beberapa negara seperti Taiwan, Malaysia, Thailand, Nepal, Sri Lanka, Kamboja, Jepang, Korea, Perancis, Jerman, Spanyol, dll (Rothan \& Byrareddy, 2020); (WHO, 2020).

di Indonesia kasus paertama terkonfirmasi pada awal Maret 2020 (Yuliana, 2020). Walaupun, pakar epidemiologi Universitas Indonesia Pandu Riono menyatakan bahwa infeksi Covid19 sudah terjadi sejak awal Februari 2019. Sehingga menurut beliau kasus positif pertama (awal Maret) tersebut bukan lagi penularan kasus impor (importer case) melainkan transmisi lokal (local transmission). Kalangan akademisi menilai pemerintah terkesan lambat dan menyepelekan virus ini di awal kehadirannya. Bukannya segera menutup pintu kedatangan wisatawan mancanegara, pemerintah malah menggerakkan influencer untuk mengkampanyekan pariwisata di Indonesia.

Perhatian serius pemerintah mulai terlihat pada sekitar pertengahan april 2020. semua lini dan stakeholder baik pusat maupun daerah, individu maupun kelompok secara bersama-sama bergotong royong meminimalisir dampak covid19 utamanya pada sektor ekonomi. Di sisi pemerintah sendiri beberapa bantuan sosial (Bansos), Jaring Pengaman Sosial (JPS) di luncurkan. Beberapa yang sudah dan akan dilakukan dalam rangka meminimalisir dampak sosial ekonomi diantaranya, yaitu: Program Keluarga Harapan (PKH), BPNT/Program Sembako, Bantuan Sosial Tunai (BST) Kemensos, BST Dana Desa, BST Provinsi, BST Kabupaten/Kota, Subsidi PLN, Kartu Pra Kerja dan lainnya. Semua program tersebut bertujuan untuk perlindungan 
sosial bagi masyarakat miskin dan rentan (Sagala, Yamin, Pratama, \& Rianawati, 2014).

Pemerintah melalui kementerian sosial merealisasikan jumlah penerima program sembako dari 15,2 juta menjadi 20 juta KPM pada tahun 2020 (Kemsos, 2020). Penambahan 4,8 juta peserta ini merupakan KPM perluasan terdampak covid19 dari penerima program yang sebelumnya dikenal sebagai Bantuan Pangan Non Tunai (BPNT). Indeks bantuan sosial yang diterima KPM pada program sembako yakni sebesar Rp.200.000,- naik dari jumlah sebelumnya Rp.150.000,-. Bantuan diterima KPM setiap awal bulan yang ditransfer langsung ke kartu Kartu Keluarga Sejahtera (KKS) mereka. Berdasarkan pedoman umum Program Sembako (Pedum sembako, 2019) KPM membelanjakan uang bantuan tersebut dengan komoditas bahan pangan seperti: Beras, Sagu, Jagung, Daging, Ikan, Telur, Tahu, Tempe, Sayuran dan buah-buahan. Pembelian paket sembako tersebut dapat dilakukan di E-Warong maupun Rumah Pangan Kita (RPK) terdekat.

E-Warong Berkah Harapan merupakan salah satu tempat pembelian paket program sembako. E-Warong ini merupakan salah satu dari $25 \mathrm{E}$-Warong yang ada di wilayah kota Pekanbaru. Berdasarkan hasil kunjungan tim pada saat pra-pengabdian, setidaknya ada sekitar 300-400 orang KPM yang melakukan pembelian sembako. Kita bisa bayangkan keramaian pada saat pembelian tersebut. Jika upaya edukasi/penyuluhan tidak dilakukan maka dikhawatirkan akan ada cluster baru dalam penyebaran covid19 yang tentu saja bisa berpotensi menambah jumlah kasus positif.

Sesuai dengan Peraturan Walikota (Perwako) Kota Pekanbaru No 104 Tahun 2020, menegaskan bahwa lingkungan tempat kerja dan usaha wajib memperhatikan protokol kesehatan berupa penyediaan tempat cuci tangan, penggunaan masker, penerapan physical distancing. Untuk itu, guna melakukan upaya pencegahan dan untuk mendukung Perwako tersebut tim pengabdi melakukan pengabdian kepada masyarakat dengan tema "Peningkatan Pengetahuan Pengurus e-Warong dalam adaptasi kebiasaan hidup baru pasca pandemi Covid19".

\section{METODE}

Kegiatan pengabdian ini diadakan di e-Warong Berkah Harapan yang terletak di Jalan Handayani II, Kota Pekanbaru. Beberapa tahapan dalam pelaksanaan pengabdian ini meliputi:

\section{a. Persiapan}

Kelompok yang menjadi sasaran pengabdian ini adalah pengurus eWarong Berkah Harapan yang berlokasi di Kelurahan Perhentian Marpoyan, Kecamatan Marpoyan Damai, Kota Pekanbaru. Peningkatan pengetahuan ini diberikan pada pengurus e-warong yang dalam kesehariannya berhadapan langsung dengan banyak orang. Tim melakukan beberapa persiapan sebelum pengabdian ini diantaranya, menghubungi penyelia e-Warong, pendamping $\mathrm{PKH}$ setempat tentang rencana kegiatan pengabdian. Selanjutnya juga dilakukan komunikasi dengan pengurus e-warong berkaitan dengan kegiatan yang dimaksud, untuk 
akhirnya menetapkan hari dan tanggal kegiatan.

Persiapan lain yang tim juga lakukan adalah menyiapkan keperluan alat pelindung diri bagi para mitra diantaranya: face shield, masker, hand sanitizer, sarung tangan plastik, sabun cuci tangan. Selain itu tim juga menyiapkan tong cuci tangan untuk pengurus e-Warong dan KPM.

\section{b. Pelaksanaan}

Kegiatan pengabdian dilaksanakan dengan metode ceramah, tanya jawab dan demonstrasi cuci tangan pakai sabun, juga disertai penilaian Pre-test dan Posttest. Penyuluhan dan demonstrasi dilakukan secara tatap muka dan memperhatikan protocol kesehatan, menggunakan bantuan poster dan perangkat cuci tangan. Tahapan pelaksanaan pada Pengabdian Masyarakat ini adalah sebagai berikut :

1. Membagikan soal pre-test untuk menilai pengetahuan awal mitra.

2. Memberikan edukasi mengenai penularan dan bahaya virus Covid19.

3. Memberikan edukasi tentang pola hidup bersih dan sehat di tempat usaha.

4. Demonstrasi cara mencuci tangan kepada masyarakat.

5. Membagikan soal post-test

\section{c. Evaluasi}

Akhir acara tim membagikan soal post-test. Ini bertujuan untuk mengetahui daya serap mitra dalam menerima materi. Keberhasilan dapat juga dilihat berdasarkan hasil post-test yang diberikan setelah penyampaian materi. Kegiatan pengabdian ini juga dievaluasi melalui peninjauan langsung saat pelaksanaan penyaluran bantuan Sembako pada bulan berikutnya. Hal ini dilakukan untuk mengetahui apakah protokol covid19 sudah dijalankan atau belum. Dari kedua hasil evaluasi ini kita dapat melihat dan membandingkan penyaluran bantuan sebelum dan sesudah dilakukannya kegiatan pengabdian.

\section{HASIL DAN PEMBAHASAN}

Kegiatan pengabdian kepada masyarakat ini dilakukan dalam upaya berbagi ilmu dan informasi tentang meningkatkan pengetahuan pengurus eWarong terhadap bahaya covid19, cara pencegahan, bentuk penularan serta promosi pola hidup bersih sehat. Kegiatan ini dilaksanakan pada bulan Juni 2020 bertempat di e-Warong Berkah Harapan, Kelurahan Perhentian Marpoyan, Kecamatan Marpoyan Damai, Kota Pekanbaru.

Perilaku hidup bersih dan sehat merupakan upaya untuk menularkan pengalaman baik ke individu atau kelompok masyarakat yang lebih luas. Beberapa upaya yang dapat dilakukan adalah dengan membagikan/memberikan materi edukasi guna menambah serta meningkatkan sikap dan perilaku hidup yang bersih dan sehat (Fatmawati, Ariyanto, \& Nurfitriani, 2019). Salah satu caranya adalah dengan memberikan penyuluhan dan pendidikan kesehatan. Penyuluhan adalah salah satu upaya untuk meningkatkan pengetahuan. Hal ini sejalan dengan Beberapa hasil penelitian yang dilakukan oleh (Syamsuar, Alam, \& Sari, 2018), (Inayah, A, \& Aini, 2018), (Isnainy et al, 2020), (Sukri, Syuryadi, \& 
Ernalia, 2020), dimana penyuluhan dapat meningkatkan pengetahuan mitra.

Kegiatan diikuti oleh 12 orang mitra. Selain pengurus juga dihadiri oleh pendamping $\mathrm{PKH}$ yang bertugas di kecamatan tersebut. Perkenalan awal menandai awal pelaksanaan kegiatan ini. Sesaat sebelum penyampaian materi, tim membagikan soal pre test untuk mengetahui pengetahuan awal mitra dalam tema ini.

Hasil pre-test sendiri dapat kita lihat pada tabel berikut:

Tabel 2. Hasil pre-test

\begin{tabular}{cccc}
\hline Skor & $\begin{array}{c}\text { Rata- } \\
\text { rata }\end{array}$ & $\begin{array}{c}\text { Std. } \\
\text { Deviasi }\end{array}$ & $\mathrm{N}$ \\
\hline $\begin{array}{c}\text { pre- } \\
\text { test }\end{array}$ & 49,77 & 12,95 & 12 \\
\hline
\end{tabular}

Sumber data: Data diolah 2020

Hasil pre-test tersebut menunjukkan bahwa rata-rata skor tes yang diperoleh menunjukkan hasil yang cukup rendah. Berdasarkan hasil penelaahan, ada beberapa soal pre-test yang diajukan tim dimana tidak satupun yang menjawab soal tersebut dengan "benar" atau mengetahui terhadap pengetahuan tersebut. Sehingga tim pengabdi menilai soal dengan jawaban terendah menjadi fokus tim dalam penyampaian materi.

Untuk menambah pengetahuan mitra maka dilakukan presentasi materi cara menjaga kesehatan, serta protocolprotokol kesehatan selama masa pandemi. Salah satu cara menjaga kesehatan tubuh adalah dengan senantiasa membersihkan tangan. Selain sebagai upaya menjaga pola hidup sehat mencuci tangan dengan sabun dapat mengurangi dan membunuh mikroorganisme, bakteri, mengurangi penyakit pernapasan dan dapat membunuh virus penyebab penyakit (Dahlan dan Umrah, 2013); (Chittleborough, Nicholson, Young, Bell, \& Campbell, 2013). Mencuci tangan secara rajin, terus dan teratur perlu digalakkan sehingga hal ini menjadi kebiasaan dalam keseharian.

Berikut adalah beberapa momen dari kegiatan pengabdian masyarakat yang tersaji dalam foto berikut:
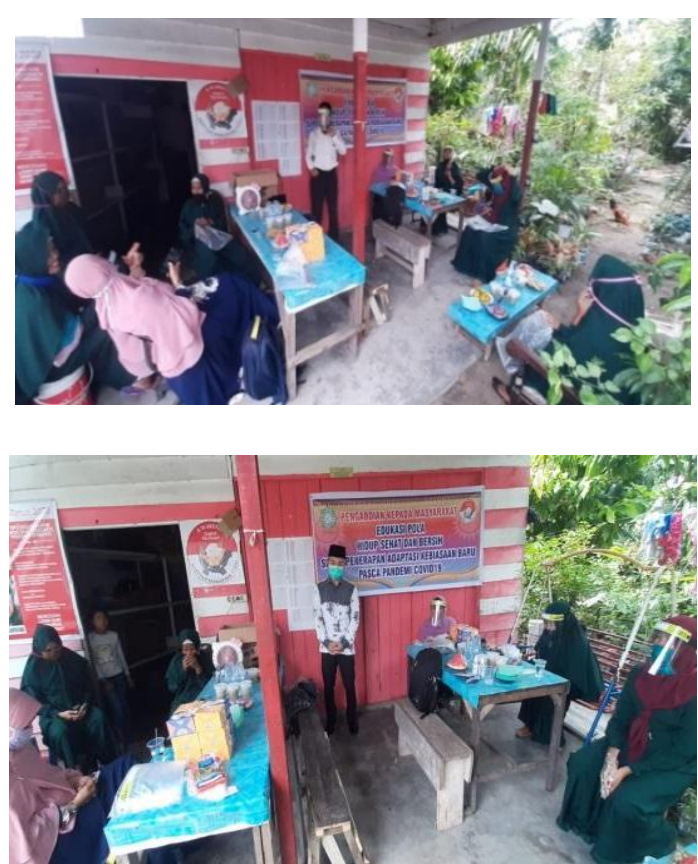

Gambar 2. Penyampaian materi penyuluhan

Disamping penyampaian materi tim juga memberikan kesempatan kepada mitra untuk bertanya seputar covid19, pola hidup bersih dan sehat guna menjaga imunitas tubuh. Beberapa pertanyaan yang muncul dari peserta pada sesi tanya jawab seperti bagaimana seseorang bisa terinfeksi COVID19, Berapa lama virus ini bertahan di atas permukaan benda, Apa yang membedakan flu akibat infeksi covid19 dengan flu dan demam pada orang biasa. 
Seluruh pertanyaan yang diajukan mitra dapat dijawab dengan baik oleh tim pengabdi.

Selain itu tim pengabdi juga menekankan bahwa sangat penting untuk mengonsumsi makanan bergizi dalam menjaga daya tahan tubuh. Tim juga menyarankan peserta untuk memanfaatkan lahan pekarangan untuk menanam apotik hidup. Serta mengajak mitra untuk terus menerapkan protokol Covid19 di lingkungan e-Warong dengan senantiasa melakukan Cuci Tangan Pakai Sabun (CTPS). Dengan melakukan demonstrasi CTPS dan edukasi tentang bahaya Covid19, masyarakat diharapkan akan sadar dan menjaga kebersihan dan kesehatan serta menjaga diri dari potensi penularan covid19.

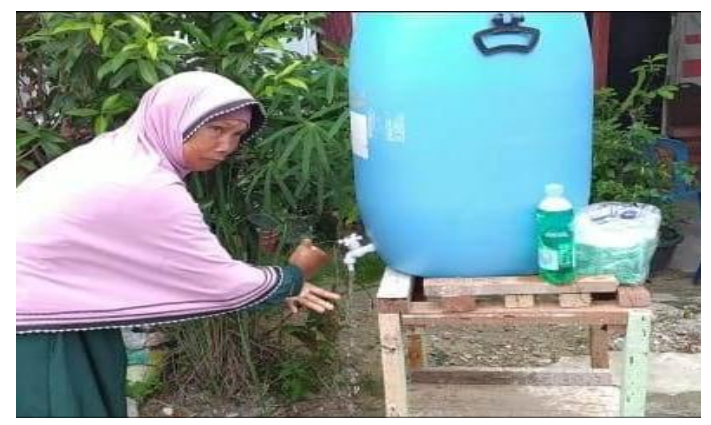

Gambar 3. Demonstrasi Cuci Tangan Pakai Sabun (CTPS)

Akhir dari sesi materi dan demonstrasi CTPS tim pengabdi gunakan untuk menyebarkan soal post-test. Jawaban post-test ini akan menjadi tolak ukur dari berhasil tidaknya kegiatan ini. Hasil post-test tersebut dapat kita lihat pada tabel berikut:

Tabel 3. Hasil pre-test

\begin{tabular}{cccc}
\hline Skor & $\begin{array}{c}\text { Rata- } \\
\text { rata }\end{array}$ & $\begin{array}{c}\text { Std. } \\
\text { Deviasi }\end{array}$ & $\mathrm{N}$ \\
\hline $\begin{array}{c}\text { pre- } \\
\text { test }\end{array}$ & 91,14 & 11,22 & 12 \\
\hline
\end{tabular}

Sumber data: Data diolah 2020
Hasil post-test menunjukkan kenaikan yang cukup tinggi dengan rata rata skor 91,14. Kenaikan dari hasil jawaban post-test ini menunjukkan pengetahuan pengurus yang bertambah dari sebelumnya. Tim pengabdi berharap materi yang diberikan hari ini dapat diaplikasikan sehingga kerumunan yang terjadi pada setiap penyaluran bantuan BPNT/Sembako tidak menimbulkan cluster baru penularan covid19.

Kegiatan pengabdian berakhir dengan sesi foto bersama dan penyerahan perlengkapan alat pelindung diri untuk pengurus berupa face shield, masker, hand sanitizer, sabun cuci tangan, sarung tangan plastik dan tong cuci tangan. Dengan pemberian bantuan ini, kekhawatiran pengurus akan penularan covid19 sedikit berkurang sehingga pengurus dapat melakukan pekerjaanya dengan baik dan lancar.

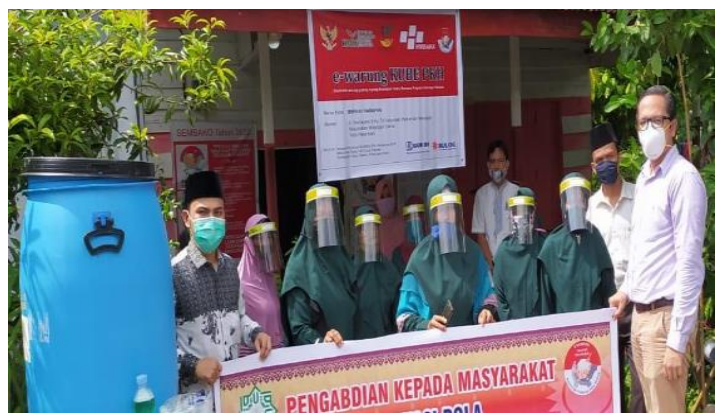

Gambar 4. Foto Bersama setelah kegiatan pengabdian

\section{SIMPULAN}

Pandemi covid19 memaksa kita untuk melakukan perubahan extrim dalam kehidupan sehari hari. Interaksi sosial, ekonomi, budaya hingga beribadah tak luput dari penyesuaian. Inilah momentum kita untuk beradaptasi dengan cara hidup baru sehingga dapat melewati pandemi yang menyebar secara global ini. Perubahan memang 
memberatkan dan seringkali membuat kita tidak nyaman namun itu harus tetap dikerjakan dengan sikap sabar, terus belajar, berpikir positif dan beradaptasi dengan perubahan.

Kegiatan pengabdian kepada masyarakat yang dilakukan para Dosen di lingkungan Civitas Akademika UIN Sultan Syarif kasim Riau ini sudah berjalan dengan baik. Mitra merasakan sekali manfaat atas kegiatan ini. terlebih dengan bantuan alat pelindung diri dan tong cuci tangan yang selama ini memang dibutuhkan oleh mitra.

\section{UCAPAN TERIMA KASIH}

Ucapan terima kasih kami sampaikan kepada pendamping PKH Rahmadhani, S.Psi yang intens berkomunikasi dengan tim pengabdi serta memberikan dukungan dan sambutan begitu hangat kepada pengabdi. Selanjutnya kepada pengurus e-Warong yang sudah bersedia meluangkan waktunya sehingga kegiatan ini terlaksana dengan baik. Kepada Lembaga Penelitian dan Pengabdian (LP2M) UIN Sultan Syarif Kasim Riau yang memberikan kepercayaan kepada kami untuk melaksanakan pengabdian ini.

\section{DAFTAR PUSTAKA}

Alsukri, S., Syuryadi, N., \& Ernalia, Y. (2020). PENINGKATAN PENGETAHUAN GIZI SEIMBANG DAN MITOS SEPUTAR GIZI PADA KELUARGA PRA-SEJAHTERA DI KELURAHAN DELIMA PEKANBARU. Martabe: Jurnal Pengabdian Kepada Masyarakat, 3(1), 108-115.
Biro Humas. 2020. Realisasikanpenambahan 48 juta-keluargapenerima-sembako. https://kemensos.go.id/. Diakses: 14 Agustus 2020

Chittleborough, C. R., Nicholson, A. L., Young, E., Bell, S., \& Campbell, R. (2013). Implementation of an educational intervention to improve hand washing in primary schools: Process evaluation within a randomised controlled trial. $B M C$ Public Health. https://doi.org/10.1186/1471-245813-757

Dahlan, A. K., \& Umrah. (2013). Ajaran Ketrampilan Dasar Praktik Kebidanan. Malang: Inti Media

Fatmawati, T. Y., Ariyanto, A., \& Nurfitriani, N. (2019). PKM Peningkatan Perilaku Hidup Sehat Pada Lanjut Usia Di Panti Sosial Tresna Werdha Kota Jambi. JDinamika.https://doi.org/10.25047/j -dinamika.v4i1.1055

Isnainy, U. C. A. S., Zainaro, M. A., Novikasari, L., Ariyanti, L., \& Furqoni, P. D. (2020). Pendidikan Kesehatan Tentang Perilaku Hidup Bersih Dan Sehat (PHBS) di SMA Negeri 13 Bandar Lampung. Jurnal Kreativitas Pengabdian Kepada Masyarakat (PKM), 3(1), 27-33.

I.I., B., A., W., A., T.-B., C., H., M.U.G., K., \& K., K. (2020). Pneumonia of unknown aetiology in Wuhan, China: potential for international spread via commercial air travel. Journal of Travel Medicine. 
Inayah, R., A, A., \& Aini, L. (2018). Pengaruh Pendidikan Kesehatan Terhadap Peningkatan Pengetahuan Tentang Perilaku Hidup Bersih Sehat (PHBS) Pada Siswa Sekolah Dasar Negeri 1 Serut Kecamatan Panti Kabupaten Jember. The Indonesian Journal of Health Science. https://doi.org/10.32528/ijhs.v0i0.1 536

Lu, H., Stratton, C. W., \& Tang, Y. W. (2020). Outbreak of pneumonia of unknown etiology in Wuhan, China: The mystery and the miracle. Journal of Medical Virology. https://doi.org/10.1002/jmv.25678

Rothan, H. A., \& Byrareddy, S. N. (2020). The epidemiology and pathogenesis of coronavirus disease (COVID19) outbreak. Journal of Autoimmunity. https://doi.org/10.1016/j.jaut.2020. 102433

Sagala, S., Yamin, D., Pratama, A. A., \& Rianawati, E. (2014). Social Protection Roles in Reducing Risk and Building Resilience to Communities in Indonesia. Governance An International Journal of Policy And Administration. https://doi.org/10.1111/j.1467629X.1980.tb00220.x

Syamsuar, F., Alam, A. M., \& Sari, R. I. (2018). Meningkatkan Pendidikan dan Pembinaan Perilaku Hidup Bersih dan Sehat Masyarakat. Abdi Dosen: Jurnal Pengabdian Pada Masyarakat. https://doi.org/10.32832/abdidos.v2 i4. 220
WHO. (2020). WHO Director-General 's remarks at the media briefing on 2019-nCoV on 11 February. WHO Director General's Statement.

Yuliana. (2020). Corona virus diseases (Covid -19); Sebuah tinjauan literatur. Wellness and Healthy Magazine.

Zheng, Y. Y., Ma, Y. T., Zhang, J. Y., \& Xie, $X$. (2020). COVID19 and the cardiovascular system. Nature Reviews Cardiology. https://doi.org/10.1038/s41569020-0360-5

Kementerian Sosial. 2019. Pedoman Umum Program Sembako 2020. Tim Pengendali Pelaksanaan Penyaluran Bantuan Sosial Secara Non Tunai. Jakarta.

Peraturan Walikota Pekanbaru No 104 Tahun 2020 Tentang Pedoman Perilaku Hidup Baru Masyarakat Produktif dan Aman Dalam Pencegahan dan Pengendalian Coronavirus Disease 2019 (Covid19) di Kota Pekanbaru. 